\title{
Physiological and biochemical responses and hydration status in equines after two barrel racing courses ${ }^{1}$
}

\author{
Cláudio L.N. Gomes ${ }^{2 *}$ (D) Andressa M. Alves ${ }^{3}$, José D. Ribeiro Filho ${ }^{4}$, \\ Felipe J. Moraes Júnior ${ }^{2}$, Raimundo A. Barreto Júnior ${ }^{5}$,Rodrigo S. Fucuta ${ }^{6}$, \\ Bruna M. Ribeiro ${ }^{7}$ and Leandro M. Miranda ${ }^{8}$
}

\begin{abstract}
Gomes C.L.N., Alves A.M., Ribeiro Filho J.D., Moraes Júnior F.J., Barreto Júnior R.A., Fucuta R.S., Ribeiro B.M. \& Miranda L.M. 2020. Physiological and biochemical responses and hydration status in equines after two barrel racing courses. Pesquisa Veterinária Brasileira 40(12):992-1001. Departamento de Clínicas Veterinárias, Universidade Estadual do Maranhão, Cidade Universitária Paulo VI, Bairro Tirirical, São Luis, MA 65055-970, Brazil. E-mail: claudioninagomes@uol.com.br

Studies on biochemical constituents and hydration of horses in training or competitions are essential for the knowledge of their adaptive physiological and metabolic responses to the type of exercise inherent to the sport. The present research evaluated the effects of exercise on hydric status and physiologic and biochemical profiles in Quarter Horses during a barrel race training session. The design consisted of three evaluation times (T): at rest, before the start of physical activity (T0); immediately after a 10-minute warm-up trot and then running the barrel race courses twice with a 10-minute interval (T1); and after one hour's rest after the second course (T2). The parameters analyzed were: heart rate (HR), respiratory rate (RR), body temperature (BT) and mucose color; the capillary refill time (CRT), packed cell volume (PCV), total plasma proteins (TPP), serum creatinine (CRE) and blood urea nitrogen (BUN) were evaluated and used to infer water status; plasma osmolarity (Osm) was measured; the electrolytes sodium $(\mathrm{Na})$, potassium $(\mathrm{K})$, chloride $(\mathrm{Cl})$, total calcium $(\mathrm{tCa})$, total magnesium $(\mathrm{tMg})$ and phosphorus (P), plasma glucose (Glu) and lactate (Lac) and the muscle enzymes creattine kinase (CK) and aspartate aminotransferase (AST) completed the evaluated parameters. The data for the variables studied were submitted to ANOVA and the Tukey test at $5 \%$ probability. After exercise (in T1), HR, RR, BT, PCV, TPP, Glu, Lac, Cre increased $(P<0.05)$, there was also increase in phosphorus and decrease in $\mathrm{K}(P<0.05)$, but there was no hypophosphatemia and hipokalemia, respectively. After rest (in T2), only glucose returned to baseline levels (T0) and, with lower mean values, HR, RR, BT, PCV, K and Lac did not return to baseline levels (T0), while P decreased $(P<0.05)$. Osm, BUN, Na, $\mathrm{Cl}, \mathrm{tCa}, \mathrm{tMg}, \mathrm{CK}$ and AST did not change between times $(P>0.05)$. It was concluded that the maximum intensity exercise performed on two barrel race courses caused mild hemoconcentration, did not changed plasma osmolality or concentrations of important electrolytes and muscle enzymes of horses, but caused hyperlactatemia without the plasma lactate concentrations being fully recomposed after resting.
\end{abstract}

INDEX TERMS: Physiology, biochemistry, equines, barrel race, exercise.

\footnotetext{
${ }^{1}$ Received on September 13, 2020.

Accepted for publication on October 1, 2020.

${ }^{2}$ Departamento de Clínicas Veterinárias, Universidade Estadual do Maranhão (UEMA), Cidade Universitária Paulo VI, Bairro Tirirical, São Luís, MA 65055-970, Brazil. E-mail: fmoraesjr@hotmail.com; *Corresponding author: claudioninagomes@uol.com.br

${ }^{3}$ Master Program in Animal Science, Centro de Ciências Agrárias, Universidade Estadual do Maranhão (UEMA), Cidade Universitária Paulo VI, Bairro Tirirical, São Luís, MA 65055-970, Brazil. E-mail: andressamalves@outlook.com

${ }^{4}$ Departamento de Medicina Veterinária, Universidade Federal de Viçosa (UFV), Avenida PH Rolfs s/n, Campus Universitário, Viçosa, MG 36571-000, Brazil.E-mail: dantas@ufv.br
}

\footnotetext{
${ }^{5}$ Departamento de Medicina Veterinária, Universidade Federal Rural do Semi-Árido (UFERSA), Av. Francisco Mota, 572, bairro Costa e Silva, Mossoró, RN 59625-900, Brazil. E-mail: barreto@ufersa.edu.br

${ }^{6}$ Veterinarian. São Luís, MA, Brazil. E-mail: fucuta_2@hotmail.com

${ }^{7}$ Curso de Medicina Veterinária, Centro Universitário do Sul de Minas (UNIS), Varginha, Minas Gerais, Brazil. bruna.ribeiro.vet@gmail.com

${ }^{8}$ Laboratório de Patologia Clínica, Universidade Estadual do Maranhão (UEMA), Cidade Universitária Paulo VI, Bairro Tirirical, São Luís, MA 65055970, Brazil. E-mail: macedo.mir@gmail.com
} 
RESUMO.- [Respostas fisiológicas e bioquímicas e status de hidratação em equinos após dois percursos de três tambores]. 0 perfil bioquímico e o status de hidratação de equinos em treinamentos ou competições fornecem dados importantes das suas respostas fisiológicas e metabólicas em relação ao tipo específico de exercício em uma modalidade esportiva. No presente estudo, o status hídrico e o perfil fisiológico-bioquímico de equinos foram avaliados durante treinamento de três tambores, em três tempos (T): em repouso, antes do início da atividade física (T0); imediatamente após 10 minutos de aquecimento ao trote seguido de duas corridas na pista de tambor, intervaladas em 10 minutos (T1); e após uma hora de descanso do segundo percurso (T2). Os parâmetros avaliados foram: frequência cardíaca (FC), frequência respiratória (FR), temperatura corporal (BT) e cor da mucosa; o tempo de enchimento capilar (TEC), volume globular ou hematócrito (VG), proteínas plasmáticas totais (TPP), creatinina sérica (Cre) e a ureia (Ure) foram avaliados e utilizados para inferir o estado hídrico dos animais; a osmolaridade plasmática (Osm) também foi mensurada; as concentrações dos eletrólitos sódio $(\mathrm{Na})$, potássio $(\mathrm{K})$, cloreto $(\mathrm{Cl})$, cálcio total $(\mathrm{tCa})$, magnésio total (tMg) e fósforo (P), e das enzimas musculares foram mensurados no soro, e as de glicose (Gli) e lactato (Lac) no plasma. Os dados das variáveis estudadas foram submetidos à ANOVA e ao teste de Tukey a $5 \%$ de probabilidade. Após o exercício (T1), a FC, FR, TC, VG, TPP, Gli, Lac, Cre aumentaram. 0 P também aumentou $(P<0,05)$, mas não alcançou nível de hiperfosfatemia, e o K diminuiu $(P<0,05)$, mas não ao nível de hipocalemia. Embora com médias menores, a FC, FR, TC, VG, K e o Lac não retornaram aos níveis basais (T0) após o repouso (T2), apenas a Gli, enquanto o fósforo diminuiu $(P<0,05)$. A Osm, ureia, $\mathrm{Na}, \mathrm{Cl}, \mathrm{tCa}, \mathrm{tMg}$, CK e AST não variaram entre os tempos $(P>0,05)$. Concluiu-se que, o exercício de intensidade máxima realizado em dois percursos de três tambores causou leve hemoconcentração, não alterou a osmolaridade plasmática nem importantes concentrações de eletrólitos e de enzimas musculares dos equinos, porém, causou hiperlactatemia, sem completa recomposição da concentração do lactato após uma hora de descanso.

TERMOS DE INDEXAÇÃO: Fisiologia, bioquímica, equinos, corrida de tambor, exercício.

\section{INTRODUCTION}

The type, intensity, and duration of exercise in equestrian modalities cause transitory physiological and metabolic changes in horses. Knowing these changes, it is possible to understand the responses of horses to the type of exercise and to monitor their adaptations to training (Padilha et al. 2017, Hunka et al. 2018). For this, in addition to a careful physiological examination, biochemical responses obtained in laboratory tests are essential in assessing the physical conditioning of a racing horse (Gomes et al. 2020).

During exercise, the water in the horse's body commonly varies due to the large amount of heat generated in the muscle that causes dehydration. In addition to water loss, there is loss of electrolytes such as sodium, potassium, chloride, calcium, and magnesium in the sweat. This hydroelectrolytic alteration alters plasma osmolarity, as it depends on the osmotic strength of the components present in the plasma that include, glucose, proteins, blood urea nitrogen and creatinine, in addition to the electrolytes (Lacerda-Neto et al. 2003).

High intensity exercise in short duration requires rapid energy production and consumption to support muscle work. In this metabolic process, the body intensifies anaerobic mechanisms, particularly anaerobic glycolysis, where lactic acid is generated and can increase rapidly in horses (Barbosa et al. 2016). Lactic acid is broken down into hydrogen and lactate ions, so the lactate concentrations in these tissues can infer about the levels of lactic acid in them, thus lactate has been used to indicate the capacity physical and adaptation of horses to the exercises imposed on them (Rodrigues et al. 2016, Binda et al. 2016, Gomes et al. 2019).

The Quarter Horse equine breed is classic in barrel racing competitions, in which the exercise is high intensity and of short duration, with predominance of anaerobic metabolism. The Quarter Horse breed they are present in approximately $45 \%$ of muscle fibers IIx (Snow \& Valberg 1994), what justifies it as the preferred breed for this activity. Fast-twitch muscle fibers (type IIx) have a significant capacity to store glycogen, thriving mainly in anaerobic glycolysis. These fibers are essential in performing intense and "explosive" exercises over short distances. The energy of anaerobic glycolysis starts seconds after the beginning of the exercise, however, the moles of ATP generated by glucose are low in anaerobic glycolysis when compared to aerobic glycolysis, and the accumulation of lactic acid and rapid depletion of glycogen muscle, resulting from anaerobic glycolysis, would generate early muscle fatigue (Vermeulen et al. 2017).

On the other hand, based on studies carried out on human muscle fibers, Westerblad (2016) pointed out results contesting acidosis as a factor underlying the impairment of muscle contraction in fatigued muscles, and that there is no obvious causal relationship between acidosis and reduced production of fatigue strength, therefore, acidosis would not be a significant cause of skeletal muscle fatigue. The involvement of acidosis in skeletal muscle fatigue would occur in combination with other changes induced by fatigue or indirectly. For example, extensive production of lactic acid would cause a reduction in the amount of ATP acquired from glycogen stored in muscle fiber, which would limit performance during exercises in which glycogen depletion is a key factor. Post-exercise measurements of lactate and muscle enzymes in the blood of equine athletes have been commonly used in assessing the effectiveness of training and in the diagnosis of muscle injuries as result of exercise (Janicki et. 2012).

In Brazil, the barrel racing events have official circuits endorsed by the "Associação Brasileira de Criadores de Cavalos Quarto de Milha" (ABQM) and is quite widespread in different regions of the country. only a few studies have shown physiological and laboratory results of horses in this modality (Capelleto et al. 2009, Barbosa et al. 2016, Rodrigues et al. 2016, Souza et al. 2018, Binda et al. 2016, Gomes et al. 2019, 2020), Therefore, it is important and necessary to obtain results that express the organic responses of these animals under specific climatic conditions, so that a more scientific basis can be applied in the preparation of these animals during training.

Based on this reality, the present research studied laboratory parameters of Quarter Horse in barrel race training (three barrel) in the northeast of Brazil where the modality 
is a highlight among equestrian sports. The evaluation of animals in barrel racing training will be useful to inform about the physiological and biochemical profiles of horses and, in particular, their hydration status after two courses, and whether resting for one hour is sufficient to recompose the possible homeostatic changes caused by exercise.

\section{MATERIALS AND METHODS}

The research was carried out at the "Haras Quatro Irmãos", located in the municipality of Raposa, Latitude -6.51667, Longitude -44.1833 $6^{\circ} 31^{\prime} 0^{\prime \prime}$ South, state of Maranhão, Brazil.

The horses' daily diet consisted of bulk: Tifton 85 hay (2\% of the bodyweight of the horse), divided in two supplies a day at 9 a.m. and 5 p.m.; and concentrate (Equimax Premium - IRCA Nutrição Animal, associated to Equimax Balance - IRCA Nutrição Animal), with $135 \mathrm{~g} / \mathrm{Kg}$ crude protein and $3.970 \mathrm{Kcal} \mathrm{Kg}^{-1}$ ) digestible energy, supplied at $4.0 \mathrm{~kg} /$ day: $1.5 \mathrm{~kg}$ at 6 a.m.; $1.0 \mathrm{~kg}$ at 11 a.m.; $1.5 \mathrm{~kg}$ at 3 p.m.; $60 \mathrm{~g}$ daily of mineral salt (Ircafós Equos 72 ADE - IRCA Nutrição Animal) associated with the concentrate, supplied to the animals in the morning and water ad libitum.

Ten Quarter Horses were used in the research, all raised in the same stud farm where the study was carried out. Horses were housed individually in 4.5 X 5.0 meters (m) masonry stalls, with floors covered by sawdust, a feeder, and automatic water cooler. The animals had participated in the last race in January 2016 and remained in training the following month, five days a week. The study was conducted in March 2016.

The equines were assessed (five animals/day, on two consecutive mornings): seven males and three females, five to eight years old (mean age 7.1), 360-492kg body weight (mean weight $=419.60$ ), healthy and adapted to barrel racing tests. Temperature and relative humidity $(\mathrm{T} / \mathrm{RH})$ at the beginning and at the end of the training were, respectively: $27^{\circ} \mathrm{C} / 67 \%$ and $30^{\circ} \mathrm{C} / 66 \%$ (day 1 ); $25^{\circ} \mathrm{C} / 68 \%$ and $30^{\circ} \mathrm{C} / 67 \%$ (day 2 ).

The clinical assessments and venous blood samples collect were performed at the times (T): at rest, before the start of physical activity (T0); immediately after (at most three minutes) the horses complete two three-drum racing courses, with an interval of 10 minutes between the courses in which the animals were led at a pace in a shaded and covered area. Before the first course, the horses performed a 10-minute warm-up.; and after one hour's rest, held by the halter and kept in a shaded place (T2).

The track for the barril race was prepared in a similar way to that used in competition of this modality: on soft terrain, three barrels were positioned to form a triangle. Barrels 1 and 2 formed the base of the triangle and were $27.5 \mathrm{~m}$ equidistant. Barrel 3 , positioned as the top of the triangle, was $32.0 \mathrm{~m}$ away from each of the other barrels. The start-finish line was marked parallel to an imaginary line between barrels 1 and 2, at 18.30m from these, in the opposite direction to the top of the triangle. On each course, the horse and rider sets bypassed the first barrel in a $360^{\circ}$ turn from left to right, then the second and third barrels also in a $360^{\circ}$ turn, but from right to left, and then headed for the finish line. In each course the horserider sets rounded the first drum in a $360^{\circ}$ turn from left to right, then the second and third turns also at $360^{\circ}$, but from right to left, and headed for the finish line. They then immediately proceeded to a covered sandy area next to the course to evaluate the animals and collect the samples.

Clinical parameters such as heart rate (HR), respiratory rate (RR), body temperature (BT), mucous color, capillary refill time, absence of pain and inappetence, and laboratory tests such as packed cell volume (PCV) or hematocrit, glycemia and proteinemia were evaluated. These parameters were normal in all ten animals. Heart rate and respiratory rate were evaluated by auscultation using a stethoscope (Accumed Rappaport Premium Stethoscope) for one minute immediately after completing the second course, and the rectal temperature for three minutes.

Blood samples were collected, after antisepsis, by puncturing the jugular vein, placed in a flask containing sodium fluoride to obtain plasma (vacuum siliconized flask - $4.0 \mathrm{ml}$ - sodium fluoride - Vacuette), and in siliconized flasks without anticoagulant to obtain serum (vacuum siliconized flask - $4.0 \mathrm{ml}$ without anticoagulant - Vacuette).

The serum and plasma aliquots were kept frozen at $-20^{\circ} \mathrm{C}$ until the time of the laboratory analyses, at the Laboratory of Clinical Analyses at the Federal University of Viçosa, State of Minas Gerais, Brazil. The following were measured in the serum: concentrations ([ ]) of the sodium ions $\left(\mathrm{Na}^{+}\right)$and potassium ions $\left(\mathrm{K}^{+}\right)$by flame photometry (B462 Flame Photometer Micronal, São Paulo, Brazil); concentrations of serum chloride $\left(\mathrm{Cl}^{-}\right)$, total calcium (tCa), total magnesium (tMg), blood urea nitrogen (BUN), creatinine (Cre), phosphorus (P), and aspartate aminotransferase (AST). Concentration of plasma glucose (GLU) and total proteins (TPP) were measured by multi-biochemical analyzer (HumanStar 300), and plasma osmolarity (Osm) was determined using freezing-point depression (Advanced Micro-Osmometer Model 3320 - Advanced Instruments Inc., Norwood/MA, USA).

Plasma lactate, serum creatine kinase (CK) and were measured in a semi-automatic biochemical analyzer model BIO-200 (Bioplus Products for Laboratories Ltda) at the "Laboratório de Patologia Clínica”, "Universidade Estadual do Maranhão” (UEMA), Maranhão, Brazil.

In the statistical analysis, a completely randomized block design was used with three treatments (T0, T1 and T2) in 10 replications (number of animals). The data for the variables studied were submitted to the normality test. The normality test for variables that were not normal (glucose, CK and AST) was the Shapiro-Wilk test. Glucose and AST mathematically transformed by LOG on base 10 (LOG10) and CK by 1/CK (inverse). The normal data and the data normalized were submitted to ANOVA and the Tukey test at $5 \%$ probability. The analyses were made using the statistical analysis software program 9.4/2015 (Statistical Analysis System Institute SAS Institute, SAS/STAT, USA).

\section{RESULTS AND DISCUSSION}

All values obtained in the pre-exercise or baseline (T0) time for the studied parameters were within normal limits, demonstrating that the animals presented normality (Table 1-4).

The heart rate (HR), respiratory rate (RR) and body temperature (BT) increased $(P<0.05)$ after exercise $(\mathrm{T} 1)$. Although they decreased after 1 hour's rest (T2), theses parameters were still higher than at the baseline time (T0) (Table 1). CRT did not change in the animals between times $(P>0.05)$, although the means at T2 and T3 were greater than in T1 (Table 1).

Increase in the HR, RR and BT in the present study was similar to results found by Allaam et al. (2014) when evaluating Thoroughbred Horses after exercises at the same times established in the present study. These parameters also increased in Quarter Horses immediately after a barrel racing session, and after 30 and 120 minutes (min) recovery from exercise (Binda et al. 2016). These increases can be justified by because the increase in HR in the horse during exercise 
occurs due to the increase in metabolic rates, as responses to adrenaline and glycolysis (Allaam et al. 2014), but also, to increased strength of cardiac contraction to maintain an adequate blood flow for perfusion and tissue oxygenation. Increase in RR is a response conditioned by the increase in pulmonary ventilation, the accumulation of metabolism products, decreased blood $\mathrm{pH}$ and increase in body temperature due exercise (Janicki et. 2012). The increase in body temperature is a fact commonly observed in horses after exercise. It is an expected answer, because horses have a high metabolic capacity and small surface area for heat dissipation. When exercising, approximately $20 \%$ of the metabolism in the horse's muscle cells is used for work and $80 \%$ becomes heat, increasing the body's internal heating (Wallsten et al. 2012).

The PCV increased $(P<0.05)$ after exercise (T1) (Table 2$).$ Capelleto et al. (2009) also found an increase in PCV in Quarter Horses after a three-barrel test, with slightly higher mean values than those obtained in the present study. Although slightly recomposed in $\mathrm{T} 2$, it was still increased in relation to the baseline time. The increase in PCV after exercise in the horses studied can be justified based on the following: when at rest, the horses maintain a splenic reserve of erythrocytes that, depending on the exercise, can be sent to the circulating blood by the response of the spleen to stimuli that alter sympathetic activity or as responses to plasma adrenaline concentrations. Thus, splenic erythrocytes are added to circulating ones, thus increasing the PCV in the blood and, effectively, the oxygen storage and transport capacity in erythrocyte hemoglobins. Concomitantly, blood viscosity increases. PCV also increases due to the change of fluids from the plasma to the tissues, and the increase in blood pressure and osmolarity in the muscles (Wickler \& Anderson 2000, Böning et al. 2012).

The TPP increased at T2 $(P<0.05)$ in relation to the other times (Table 2). PCV and TPP are used to diagnose dehydration in horses. Their values can characterize the hemoconcentration caused by water losses in sweat during exercise. So, it is possible that the increase in PPT in horses may have been generated by the greater loss of water in sweat and breathing that reduced the plasma volume. On the other hand, A slight increase in this marker (TPP) can be caused by a reduction in plasma volume and not by real dehydration, which can be caused by sweating (Zobba et al. 2011). Therefore, hemoconcentration can be explained by changes in intercompartmental fluid rather than a loss of corporeal fluid (McKeever et al. 1993). Demirtas (2018) considered that displacement of intercompartmental fluids may have been the reason for an increase in TPP concentrations in Arabian horses after exercises. Therefore, the increase in PCV and TPP in T1 was probably a result of water loss and, or displacement in the body, and the reductions that subsequently occurred after resting (T2), due to the return of fluids to the extracellular space that diluted the concentrations of solutes in the plasma.

Although PCV and PPT increased, signaling the presence of dehydration, this was not reflected by CRT. The CRT is also a useful parameter to infer dehydration in horses, and its increase has been seen in horses after exercise in different equestrian modalities (Wallsten et al. 2012, Binda et al. 2016, Demirtas 2018). The PCV, PPT and CRT values, analyzed together, characterized only the presence of mild dehydration in the horses (Table 1), so that the water status

Table 1. Mean values and standard deviations of heart rate, respiratory rate, rectal temperature, capillary refill time and mucous color in horses after two barrel racing courses

\begin{tabular}{|c|c|c|c|c|}
\hline \multirow{2}{*}{ Parameter } & \multirow{2}{*}{ Reference ranges } & \multicolumn{3}{|c|}{ Evaluation time (T) } \\
\hline & & T0 & $\mathrm{T} 1$ & $\mathrm{~T} 2$ \\
\hline Heart rate & $30-40 \mathrm{bpm}$ & $37.60 \pm 3.37^{\mathrm{C}}$ & $106.40 \pm 12.54^{\mathrm{A}}$ & $50.00 \pm 8.89^{\mathrm{B}}$ \\
\hline Respiratory rate & $18-20 \mathrm{rpm}$ & $19.20 \pm 2.53^{\mathrm{C}}$ & $65.40 \pm 9.43^{\mathrm{A}}$ & $36.40 \pm 8.93^{\text {В }}$ \\
\hline Rectal temperature & $37.0-38.5^{\circ} \mathrm{C}$ & $37.21 \pm 0.39^{\mathrm{B}}$ & $39.49 \pm 0.71^{\mathrm{A}}$ & $38.86 \pm 0.80^{A}$ \\
\hline Capillary refill time & $<2$ seconds & $1.20 \pm 0.42^{\mathrm{A}}$ & $1.60 \pm 0.52^{\mathrm{A}}$ & $1.60 \pm 0.70^{\mathrm{A}}$ \\
\hline Mucous color & Rose (normal) & Rose (normal) & Rose (normal) & Rose (normal) \\
\hline
\end{tabular}

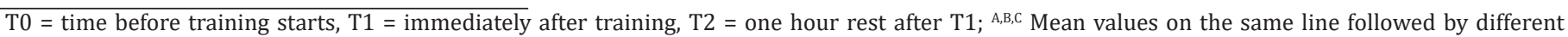
uppercase letters differ between times $(P<0.05)$ by the Tuckey test.

Table 2. Mean values and standard deviations of packed cel volume (PCV), total plasma proteins (TPP), creatinine, blood ureic nitrogen (BUN) and osmolality (Osm) in horses after two barrel racing courses

\begin{tabular}{|c|c|c|c|c|}
\hline \multirow{2}{*}{ Parameter } & \multirow{2}{*}{ Reference ranges } & \multicolumn{3}{|c|}{ Evaluation time (T) } \\
\hline & & T0 & $\mathrm{T} 1$ & $\mathrm{~T} 2$ \\
\hline PCV & $32-50 \%$ & $33.60 \pm 2.88^{\mathrm{B}}$ & $48.70 \pm 5.50^{\mathrm{A}}$ & $41.60 \pm 4.79 \mathrm{~A}^{\mathrm{B}}$ \\
\hline TPP & $5.2-7.9 \mathrm{~g} \mathrm{dL}^{-1}$ & $7.55 \pm 0.31^{\mathrm{AB}}$ & $8.85 \pm 0.40^{\mathrm{A}}$ & $7.04 \pm 0.64^{\mathrm{B}}$ \\
\hline Creatinine & $1.1-1.9 \mathrm{mg} \mathrm{dL}^{-1}$ & $1.41 \pm 0.17^{\text {B }}$ & $1.66 \pm 0.02^{\mathrm{A}}$ & $1.58 \pm 0.25^{\mathrm{AB}}$ \\
\hline BUN & $22-48 m g \mathrm{dL}^{-1}$ & $34.70 \pm 7.45^{\mathrm{A}}$ & $36.90 \pm 6.57^{\mathrm{A}}$ & $36.30 \pm 6.78^{A}$ \\
\hline Osm & $270-310 \mathrm{mMol} \mathrm{L}^{-1}$ & $298.60 \pm 16.87^{A}$ & $312.50 \pm 19.54^{\mathrm{A}}$ & $299.20 \pm 21.47^{\mathrm{A}}$ \\
\hline
\end{tabular}


uppercase letters differ between times $(P<0.05)$ by the Tuckey test. 
may not have reached a degree of hypovolemia to the point of compromising the tissue perfusion of the animals, and therefore did not alter the CRT significantly.

There was an increase $(P<0.05)$ in creatinine concentration after exercise (Table 2), corroborating results found in horses under exercise in the studies by Allann et al. (2014) and Monteiro et al. (2018). According to Toribio (2008), exercise can induce a slight increase in Cre concentrations, which is a creatine metabolism-derived product synthesized mainly in the kidneys, liver, and pancreas. In muscle, Cre is a nonenzymatic by-product derived from phosphocreatine (CPi) and its concentration is related to muscle mass and renal function. Large horses or those with large muscle mass, such as Quarter Horses, tend to have higher concentrations of creatinine. In the horse, Cre secretion and reabsorption are minimal. Therefore, increased Cre metabolism during intense physical exercise (Table 2), and the concomitant decrease in renal glomerular filtration (RGF) may have influenced its increase in T1.

Blood Urea Nitrogen (BUN) did not vary $(P>0.05)$ between the times (Table 2), corroborating with Gomes et al. (2019) who also did not detect variations in the BUN in Quarter Horses during three-barrel training, although, McGowan \& Hodgson (2014) reported that the BUN can exceed the normal limits in high or low exercise intensity, due to reduced renal blood flow or fluid loss. However, this did not occur in the present study.

There was no change in plasma osmolarity (Table 2). Osmolarity did not change between the times $(P>0.05)$ because concentrations of important osmotically active substances in the extracellular space such as sodium, BUN and glucose did not exceed normal physiological limits. A similar fact was observed by Gomes et al. (2019) in Quarter Horses after a barrel race, in which plasma osmolarity remained at normal limits and the sodium, potassium, glucose and urea values remained at normal physiological limits. The maintenance of osmolarity in exercised horses can be explained based on physiological mechanisms. Increased osmolarity and reduced blood volume are, respectively, conditions for increased secretion and release of ADH into the circulation, which stimulates was reabsorption in the kidneys, partially helping to conserve fluid in the body. Therefore, the renal adjustment of water and salt excretion corrects the plasma volume and adjustment of the plasma osmolarity (Feher 2017).
The change in blood volume as hyper or hypovolemia induces a hormonal contraction, involving renin, aldosterone, vasopressin, and natriuretic peptide, among others. However, the effects of exercise may differ with respect to sprint (short) vs endurance (long duration). Therefore, a distinct change in osmolarity does not occur in all cases. For example, in prolonged exercises, the plasma volume decreases, generating hemoconcentration, while the plasma osmolarity remains practically unchanged (Coenen 2005). This may justify the fact that dehydration occurred in the horses in the post-exercise period, without significant changes in plasma osmolarity.

There was no change in serum sodium concentrations $(P>0.05)$ between the studied times (Table 3). The results found for sodium corroborated those of Prado et al. (2019) who also did not find significant alterations in sodium in English Thoroughbred horses under intense effort. Gomes et al. (2019) also found no change in sodium concentrations in horses after a barrel race training session. Considering that the horses were already well conditioned for barrel racing, little loss of sweat sodium and renal resorption of the sodium supported the stability of this electrolyte in the test performed.

Another justification for the non-variation in sodium in exercised horses is based on systemic and renal hormonal processes. The hypothalamic-pituitary-adrenal axis (HPAA) is influential in renal sodium homeostasis, by increasing the synthesis of mineralocorticoid and by acting on the mineralocorticoid and glucocorticoid receptors in the kidneys. In this process, cortisol plays an imperative role, as it stimulates renal transport processes attributed to the renin-angiotensinaldosterone system (RAAS), and its high concentration during exercise helps to maintain the stability of sodium in the blood (Prado et al. 2019). These results suggest that there is an important mechanism for maintaining osmolarity in horses during exercise, especially in relation to sodium, the most abundant component in the extracellular space.

The potassium concentration decreased $(P<0.05)$ at the post-exercise (T1) and post-rest (T2) times (Table 3) but it remained within normal reference limits, not characterizing hypokalemia. As for potassium, the reduction of this electrolyte in horse serum was also verified by Di Filippo et al. (2009), after resistance competition, and by Linhares et al. (2017), in Mangalarga Machador horses, after completing a cavalcade, which are long duration equestrian events. These researchers raised the possibility that the decrease in potassium may also

Table 3. Mean values and standard deviations of sodium, potassium, chloride, total calcium and total magnesium in horses after two barrel racing courses

\begin{tabular}{|c|c|c|c|c|}
\hline \multirow{2}{*}{ Parameter } & \multirow{2}{*}{ Reference ranges } & \multicolumn{3}{|c|}{ Evaluation time (T) } \\
\hline & & T0 & $\mathrm{T} 1$ & $\mathrm{~T} 2$ \\
\hline Sodium & $132-145 \mathrm{mMol} \mathrm{L}^{-1}$ & $136.40 \pm 2.86^{\mathrm{A}}$ & $137.30 \pm 3.06^{\mathrm{A}}$ & $135.80 \pm 2.49^{\mathrm{A}}$ \\
\hline Potassium & $2.4-4.7 \mathrm{mMol} \mathrm{L}^{-1}$ & $3.78 \pm 0.21^{\mathrm{A}}$ & $3.52 \pm 0.21^{\mathrm{B}}$ & $3.45 \pm 0.26^{\mathrm{B}}$ \\
\hline Chloride & 99 - $109 \mathrm{mMol} \mathrm{L}^{-1}$ & $98.90 \pm 3.75^{\mathrm{A}}$ & $97.40 \pm 3.24^{\mathrm{A}}$ & $95.20 \pm 3.08^{\mathrm{A}}$ \\
\hline Total calcium & $2.8-3.4 \mathrm{mMol} \mathrm{L}^{-1}$ & $2.97 \pm 0.26^{\mathrm{A}}$ & $3.02 \pm 3.24^{\mathrm{A}}$ & $3.02 \pm 0.29^{A}$ \\
\hline Total magnesium & $0.9-1.5 \mathrm{mg} \mathrm{dL}^{-1}$ & $0.90 \pm 0.08^{\mathrm{A}}$ & $0.95 \pm 0.15^{\mathrm{A}}$ & $0.86 \pm 0.14^{\mathrm{A}}$ \\
\hline
\end{tabular}

$\mathrm{T} 0=$ time before training starts, $\mathrm{T} 1=$ immediately after training, $\mathrm{T} 2=$ one hour rest after $\mathrm{T} 1{ }^{\mathrm{A}, \mathrm{B}}$ Mean values on the same line followed by different uppercase letters differ between times $(P<0.05)$ by the Tuckey test. 
come from metabolic control in the kidneys, in which there is renal excretion of the potassium cation $\left(\mathrm{K}^{+}\right)$and hydrogen proton $\left(\mathrm{H}^{+}\right)$, and reabsorption of the sodium cation $\left(\mathrm{Na}^{+}\right)$.

On the other hand, a decrease in post-exercise serum potassium was also observed in horses by Lacerda-Neto et al. (2003), after the animals performed low intensity exercise. Barbosa et al. (2016) also found a decrease in this electrolyte in horses, after a barrel race, but the concentration remained within normal concentrations for the species, similar to the results found in the present study. Another reason to justify this fact was presented by Muriel (2007) who stated that decrease in potassium can occur due to its rapid entry into the muscle cell after the interruption of exercise, by the action of the $\mathrm{Na}^{+}-\mathrm{K}^{+}$pump that reduces its concentration in the blood.

In the present study, there was no change in chloride concentrations between the times $(P>0.05)$ (Table 3). Chloride is the most concentrated electrolyte in the horse's sweat. More intense exercises cause greater chloride losses in sweating, which can reduce its serum concentration (Lacerda-Neto et al. 2003). A reduction in serum chloride was also observed in horses submitted to polo (Monteiro et al. 2018). However, Walker \& Collins (2017) also did not observe changes in chloride in horses immediately following 20 minutes trotting, and immediately following a $2 \mathrm{~min}$ race. In the present study, the intensity of the exercise during two courses may not have caused significant chloride losses in the animals' sweat, preserving its normal blood concentrations. On the other hand, there are organic mechanisms that favor the cationanion balance in the body, since $\left[\mathrm{Cl}^{-}\right]$tends to be regulated secondarily to $\left[\mathrm{Na}^{+}\right]$(Muriel 2007), which may also have influenced the results found, since sodium also did not vary during the three evaluation times adopted in this research.

The total calcium concentrations assessed in the horses also did not vary between times $(P>0.05)$ (Table 3$)$. Brazilian sport horses adapted and trained in a tropical climate, when submitted to training that consisted of flatwork exercises, aerobic conditioning and jumping over track and nature obstacles, also showed no serum calcium variations (Padilha et al. 2017). On the other hand, Crocomo et al. (2009) verified increased calcium in the blood of PSI horses after high intensity and long duration exercise. According to Coenen (2005), the influence of exercise on requirements for calcium is low, because it is possible that, due to the action of parathormone, the mobilization of calcium from the tissue to the blood is maintained, preserving its concentrations. So, it is also possible that [Ca] did not vary in the animals because the effort was not long, causing little perspiration and little loss of calcium in the sweat.

The total magnesium concentrations also did not vary significantly in the present study $(P>0.05)$ (Table 3$)$. Likewise, in a polo game, Monteiro et al. (2018) found no variation in serum magnesium in horses. On the other hand, Crocomo et al. (2009) found increased values of serum magnesium in PSI horses submitted to a 2000 meters gallop. In highintensity exercise, the magnesium concentration increases because adenosines mono and diphosphate have much less affinity for magnesium than for ATP ions (Demirtas et al. 2015). The evaluation of magnesium in the blood of horses during physical activities is of great importance, because during muscle activity its concentration increases in the sarcoplasm, which reduces the flow of calcium through the sarcoplasmic reticulum membrane, generating muscle fatigue (Demirtas et al. 2015). However, as there are few studies on serum magnesium in horses and the results obtained are still mixed, further studies are needed to understand the effects of physical effort on magnesium concentrations in horses.

The phosphorus concentration was increased at T1 $(P<0.05)$ (Table 4). Similar results were obtained in horses after intense exercise by Piccione et al. (2007) in PSI. Results without phosphorus variation after intense and maximum exercise in PSI horses were reported by Crocomo et al. (2009). This increase may be subsequent to ATP dephosphorylation to provide high energy phosphate for muscle contraction, due to the greater loss of vascular compartment fluid in proportion to phosphorus (Rose et al. 1993) or by adrenergic stimulation during intense physical exercise inducing parathyroid hormone (PTH), with subsequent increase in circulation phosphorus (Piccione et al. 2007, Crocomo et al. 2009). Moreira et al. (2015) found an increase in phosphorus in military horses after urban patrolling carried out both in the morning and afternoon, and considered that the increase may have occurred due to the reduction in the glomerular filtration rate (GFR) of this ion as a result of the exercise, because, during exercise, renal blood flow is reduced to supplement an increase in cardiac output and, subsequently, peripheral blood flow, especially in the muscles. They also pointed out that, as GFT decreases, there is approximately $85 \%$ phosphorus reabsorption in the contoured proximal tubules. All the justifications of the

Table 4. Mean values and standard deviations of phosphorum, glucose, lactate, creatine kinase (CK) and aspartate aminotransferase (AST) in horses after two barrel racing courses

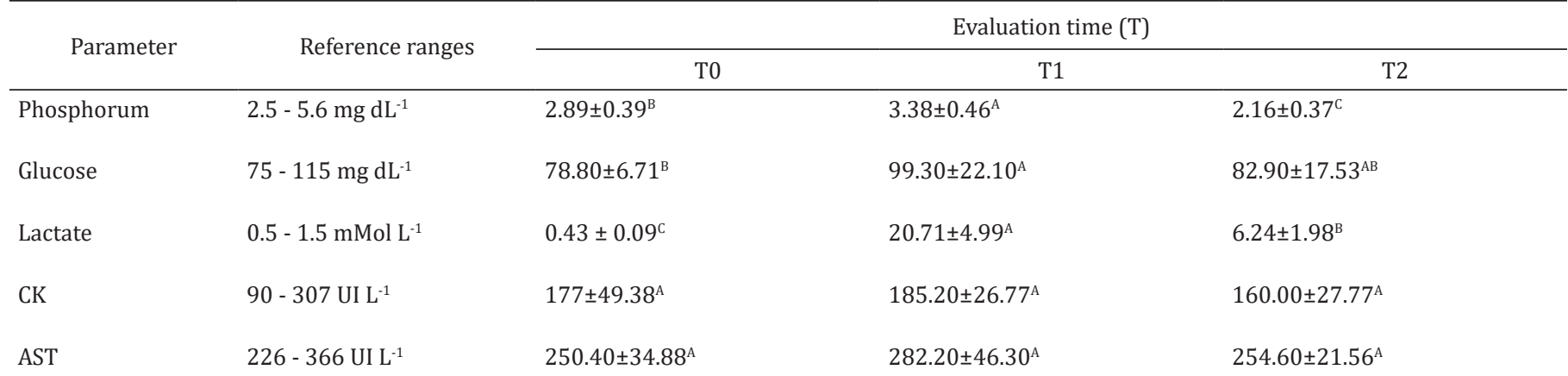

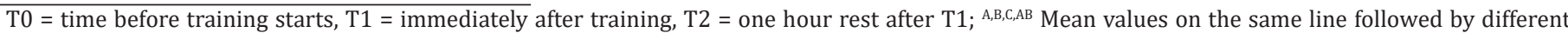
uppercase letters differ between times $(P<0.05)$ by the Tuckey test. 
respective authors mentioned in the paragraph also serve to support the increase in post-exercise phosphorus in the animals of the present study.

Phosphorus decreased at $\mathrm{T} 2$ in relation to $\mathrm{T} 0$ and $\mathrm{T} 1$ $(P<0.05)$ (Table 3$)$. Considering that phosphorum is extremely important for the formation of the ATP used as a source of energy in body aerobic metabolismo (Rose et al. 1993, Piccione et al. 2007), it is possible that this electrolyte was returned to the intracellular medium, thereby decreasing the serum concentrations previously increased by T1. Therefore, a physiological variation.

The glucose concentration increased in T1 $(P<0.05)$, differing from $\mathrm{T} 0$ and $\mathrm{T} 2$ (Table 4) but it remained within normal reference limits, not characterizing hyperglicemia. Despite the significant variation in glucose, its mean values remained within the normal limits of reference at the three evaluation times, corroborating with Rodrigues et al. (2016) who also did not obtain an increase in the plasma glucose of Quarter Horses after a simulated barrel race exercise. On the other hand, the average values of the present study are still lower than those reported by McGowan \& Hodgson (2014), of concentrations of 180 to $206 \mathrm{mg} \mathrm{dL}^{-1}$ in horses that performed high intensity short duration exercises. Barbosa et al. (2016) also found an increase in blood glucose in horses immediately after a barrel race exercise, as also Souza et al. (2018), in Quarter Horses, immediately after the second three-barrel course.

Some studies have reported that the increase in blood glucose after exercise may be due to hepatic glycogenolysis and gluconeogenesis, in response to the energetic need to maintain muscle activity (Allaam et al. 2014), and because of the increase in blood cortisol and catecholamines, with concomitant reduction insulin, causing an increase in blood glucose (Barbosa et al. 2016). However, the lactate is the main non-glycidic substrate for glucose synthesis (gluconeogenesis) during high intensity exercises. In high intensity and short duration exercise - such as the barrel race - the excess of pyruvic acid produced is biotransformed into lactate. In red blood cells as well as the exercising muscle tissue that favors anaerobic metabolism, glucose is converted to pyruvate and subsequently to lactate. Lactate is secreted into plasma and picked up by the liver for conversion into glucose in Cori cycle via a redox reaction catalyzed by lactate dehydrogenase (Draoui \& Feron 2011).

Plasma lactate concentration increased at T1 $(P<0.05)$ (Table 4), reaching limits of hyperlactatemia: $>5 \mathrm{mMol} \mathrm{L}^{-1}$ (Goméz e Mizok. 2017). Comparing lactate increases after exercise in the horses studied, similar results were seen in Quarter Horses during barrel race (Rodrigues et al. 2016, Souza et al. 2018) and "vaquejada" (Binda et al. 2016). This increase occurred because anaerobic glycolysis is a rapid ATP production pathway caused by the partial break down of glucose. In this process, lactic acid is fractioned into hydrogen and lactate as the product of this glycolytic metabolismo (Barbosa et al. 2016) and both increase in the blood.

It is of great importance to highlight that the increase in blood lactate concentration is called hyperlactatemia, which may or may not be associated with acidemia $(\mathrm{pH}<7.35)$. Lactic acidosis is a situation where lactate production exceeds clearance and acidemia and hyperlactatemia occur simultaneously. Although used as a marker of anaerobic metabolism and tissue hypoxia, lactate is not a "malignant" molecule and not only a residual product of anaerobiosis, but a fundamental participant in metabolism and energy homeostasis, being produced from pyruvate reduction by the action of the enzyme lactate dehydrogenase (LDH) in different cells in the body, mainly in skeletal muscle, skin, brain and red blood cells (Goméz e Mizok 2017).

A slight recomposition of lactate concentration was observed after resting. But, although decreased in T2 compared to T1 $(P<0.05)$, it remained higher than at T0 $(P<0.05)$, and at levels of discrete hyperlactatemia (Table 4). Similarly, Gomes et al. $(2019,2020)$ also did not find recovery of the plasma lactate concentration in Quarter Horses after resting for $40 \mathrm{~min}$ at the end of a course, and after resting for $60 \mathrm{~min}$ at the end of two three-drum courses, respectively. However, Allaam et al. (2014) obtained a significant increase in lactate in Throroughbred Horses, five minutes after exercise, which returned to baseline levels after one hour of rest. Lactate recomposition after rest is attributed to gluconeogenesis that metabolizes lactate to glucose. As for the consumption of lactate circulating in the body, its uptake and daily release occur mainly in the liver and kidneys, which use it as a substrate for the regeneration of glucose through the process of gluconeogenesis. But, during resting conditions, it is also partially metabolized by oxidation in many organs such as the heart, brain, and skeletal muscle, through the Krebs cycle, to generate adenosine triphosphate (ATP) (Goméz and Mizok 2017).

Plasma lactate concentrations depend on your turnover (lactate synthesis minus its uptake in tissues). At the end of the exercise, it is lower than that produced during the exercise due to the uptake of lactate by the tissues, including neoglycogenesis (Benetti et al. 2000). Based on this, an athlete under frequent training could have a greater capacity for neoglycogenesis than an untrained one. So, this can be useful for Veterinarians and trainers in conditioning sports horses during training and equestrian events, not with the sole concern that horses show less post-exercise lactate production, but the ability to consume and recompose concentrations of lactate after the end of the exercise. This can be accomplished by comparing the neoglycogenic activity of the equine athlete to the type of exercise, verifying whether after an exercise under a specific intensity and duration, plasma lactate concentrations in trained horses are lower in relation to those of untrained, suggesting an increase in neoglycogenic activity.

CK and AST are proteins released after the increased permeability of sarcolemma in the musculoskeletal cell, due to physical effort, which, when intense, can generate acute muscle damage (Padilha et al. 2017). Binda et al. (2016), also did not find variation in the enzymes CK and AST in horses after barrel race exercise in tropical conditions, and neither did Hunka et al. (2018) in puller or vaquejada helper horses, and attributed this to the fact that the animals were in good physical condition for this purpose. Likewise, the horses in the present study were also adapted and in continuous barrel racing activity, with good adaptation and good muscle conditioning.

The values of CK and AST did not differ between the evaluated times $(P>0.05)$ and were within normal limits (Table 4). Rodrigues et al. (2016) found a higher mean serum CK concentration in horses in a simulated barrel race, after a four-hour rest at the end of the exercise, even greater than that 
obtained immediately after the exercise. These researchers also found no significant variations for [AST]. Assessing serum amyloid A (SAA) protein, CK and AST in ten horses that had jumped over a meter high obstacles, Carvalho Filho et al. (2019), found no significant difference in the biomarkers SAA and AST between the pre-exercise moments, and $30 \mathrm{~min}$, $60 \mathrm{~min}$ and $24 \mathrm{~h}$ post-exercise, the CK increased after $30 \mathrm{~min}$ from the end of the exercise, but was already stabilized in $24 \mathrm{~h}$.

According to Barrelet \& Ricketts (2002), repetitive and adequate exercises induce the physiological adaptation of horses to stress exercise, reducing extracellular changes harmful to muscle cells. So, as [CK] and [AST] are related to exercise type and intensity, it is possible that, by the end of two barrel races, the intensity did not reach a degree of effort beyond the physical conditioning that the animals were already adapted to perform and there was no influence on the values of these enzymes. However, it is important to consider that the maximum CK peak occurs between 6 and 12 hours after muscle injury, and AST, between 24 and 36 hours, and since measurements were taken inf this study only until one hour after exercise, it is possible that their enzyme levels would have not yet reached higher concentrations in animals.

Although CK and AST have been commonly used as skeletal muscle (SKM) injury biomarkers, the certainty of the occurrence of muscle injuries based on these enzymes has been reassessed. Second Chanoit et al. (2001), the plasma CK value, which is a standard clinical marker, may be interpreted differently depending on the physical performance of the subject, and peak plasma CK activity does not provide a realistic assessment of the amount of damaged muscle, and, thus, it is a relatively crude indicator of muscle damage.

Gondin et al. (2013) analyzed the acute phase response (APR) in fifteen clinically healthy "high-goal" polo ponies of a Brazilian elite polo team by quantifying the physiological variables of venous blood and acute phase proteins (APP) 5 minutes, 6 and 12 hours after a pole training, which is of high intensity for all positions of the game in which horses are used. The researchers found that changes in muscle membrane permeability occurred in all horses, based on that of CK without correlation with APR, and a significant increase in total serum proteins, albumin, ceroplasmin, haptoglobin, alpha- 1 antitrypsin, and 23-kDa proteins during the physical effort of the match, demonstrating that high intensity exercise at the equestrian pole causes an acute phase response of relatively short duration and non-inflammatory, and that the change in APR was just a variation related to physiological stress as a function of exercise.

Skeletal troponin I (sTnI), myosin light chain 3 (Myl3), and creatine kinase muscle isoform $(\mathrm{CKm})$ proteins have been shown recently to be biomarkers more sensitive and specific for monitoring drug-induced SKM injury in rat toxicology studies (Vlasakova et al. 2017). Quantitative measurement of sTnI, Myl3, CKm and lipid transport protein fatty acid binding protein 3 (FABP3) were studied by Burch et al. (2015) in human serum with important muscular dystrophies and compared with the plasma CK concentration, aiming to verify if these proteins would better reflect the patients' disease state than the CK activity. The authors concluded that the different profiles of these proteins in the three muscular dystrophies suggested different mechanisms that regulate their release in the circulation. The potentially increased specificity for skeletal muscle injury and the correlation with clinical outcomes in the patients studied suggested that these biomarkers could be a valuable non-invasive tool for monitoring the progression of muscle disease. Vlasakova et al. (2017), obtained findings that supported the conclusion that sTnI, Myl3, and CKm are sensitive early tissue leakage biomarkers for monitoring SKM injury and effects of exercise in dog. Future research may elucidate the value of these proteins in monitoring horses with the possibility of musculoskeletal injuries, guiding the directions of clinical biochemistry regarding the use of biomarkers in equine physiology.

\section{CONCLUSION}

The maximum intensity exercise performed in two drum runs did not alter the plasma osmolality, the electrolyte and muscle enzyme concentrations of the horses, and caused only a mild hemoconcentration that was already recomposed after resting for an hour. However, it caused hyperlactatemia without the plasma lactate concentrations being fully recomposed after resting.

Acknowledgements.- The authors thank the "Fundação de Amparo à Pesquisa e ao Desenvolvimento Científico e Tecnológico do Maranhão" (FAPEMA), Maranhão, Brazil, for funding research grants for Alves A.M. (FAPEMA-BIC 02415/15) and Fucuta R.S, (FAPEMA-BIC 04190/16); "Coordenação de Aperfeiçoamento de Pessoal de Nível Superior" (CAPES), Brazil, for partial financing/Finance code 001; “Haras Quatro Irmãos”, Maranhão, Brazil, for granting the location and the horses for the animal experiment; "Laboratório de Patologia Clínica" (LPC), of the "Universidade Estadual do Maranhão" (UEMA), Maranhão, Brazil; and "Laboratório de Pesquisa em Patologia Clínica Veterinária" (LPPCV) of the "Universidade Federal de Viçosa" (UFV), Minas Gerais, Brazil, for carrying out the laboratory analyzes.

Bioethics and biossecurity committee approval.- The research was approved by the Ethics Commission on Animal Experimentation (CEEA) of the Veterinary Medicine Course at the "Universidade Estadual do Maranhão" (UEMA), Maranhão state, Brazil, protocol number 10/2016.

Conflict of interest statement.- The authors declare there are no conflicts of interest. The founding sponsors had no role in the design of the study, in the collection, analysis, or data interpretation, in the writing of the manuscript, and in the decision to publish the results.

\section{REFERENCES}

Allaam M., Elseady Y., Nayel M., Elsify A., Salama A., Hassan H., Hassan M. \& Kamar A. 2014. Physiological and hemato-chemical evaluation of thoroughbred race horse after exercise. IJAVMS 8(3):81-93.

Barbosa J.P.B., Denadai D.S., Gerardi B., Pereira M.A., Chaves A.A., Gomide L.M.W., Peiró J.R. \& Mendes L.C.N. 2016. Endoscopic airway, blood gas, electrolytes, and acid-base in equine submitted to three-barrel training. Arq. Bras. Med. Vet. Zootec. 68(5):1152-1158. <https://dx.doi. org/10.1590/1678-4162-8739>

Barrelet A. \& Ricketts S. 2002. Haemnatology and blood biochemnistry in the horse: a guide to interpretation. In Practice 24(6):318-327. <https:// dx.doi.org/10.1136/inpract.24.6.318>

Benetti M., Santos R.T. \& Carvalho T. 2000. Cinética de lactato em diferentes intensidades de exercícios e concentrações de oxigênio. Revta Bras. Med. Esporte 6(2):50-56.<https://dx.doi.org/10.1590/S1517-86922000000200004>

Binda M.B., Teixeir F.A., Carvalho R.S., Macedo L.P., Conti L.M.C., Manso Filho H.C. \& Coelho C.S. 2016. Effects of 3-Barrel racing exercise on electrocardiographic 
and on blood parameters of Quarter Horses. J. Equine Vet. Sci. 47:71-76. $<$ http://dx.doi.org/10.1016/j.jevs.2016.08.001>

Böning D., Maassen N. \& Pries A.R. 2012. The optimal hematocrit increases during exercise. J. Appl. Physiol. 113(7):1168. <http://dx.doi.org/10.1152/ japplphysiol.00957.2012>

Burch P.M., Pogoryelovac O., Goldsteina R., Bennettb D., Guglieric M., Straubc V., Bushbyc K., Lochmuller H. \& Morrisb C. 2015. Muscle-derived proteins as serum biomarkers for monitoring disease progression in three forms of muscular dystrophy. J. Neuromuscul. Dis. 2(3):241-255. <https://dx.doi. org/10.3233/JND-140066><PMid:26870665>

Capelleto E.C., Angeli A.L. \& Graff H. 2009. Physiological answers in quarter horses after barrel racing. Revta Acad. Ciênc. Agrár. Ambient. 7(3):299-304.

Carvalho Filho W.P., Fonseca L.A., Girardi F.M., Bento L.D., Souto P.C. \& Orozco A.M.O. 2019. Serum amyloid A and muscle activity biomarkers in horses submitted to equestrian show jumping. Pesq. Vet. Bras. 39(8):668-671. <https://dx.doi.org/10.1590/1678-5150-PVB-6218>

Chanoit G.P., Lefebvre, H.P., Orcel K., Laroute V., Toutain P.L. \& Braun J. 2001. Use of plasma creatine kinase pharmacokinetics to estimate the amount of exercise-induced muscle damage in Beagles. Am. J. Vet. Res. 62(9):13751380. <http://dx.doi.org/10.2460/ajvr.2001.62.1375><PMid:11560263>

Coenen M. 2005. Exercise and stress: impact on adaptive processes involning water and electrolytes. Livest. Prod. Sci. 92(2):131-135. <https://dx.doi. org/10.1016/j.livprodsci.2004.11.018>

Crocomo L.F., Balarin M.R.S., Takahira R.K. \& Lopes R.S. 2009. Serum macro minerals in adults thoroughbred horses, before and after the high intensity exercise. Revta Bras. Sáude Prod. Anim. 10(4):11-16.

Demirtas B. 2018. Physical, haematological and biochemical responses of arabian horses to jereed (Javelin Swarm) competition. Kafkas Univ. Vet. Fak. Derg. 24(2):219-226. <http://dx.doi.org/10.9775/kvfd.2017.18674>

Demirtas B., Yaramis C.P. \& Atmaca M. 2015. Exercise-induced physiological fatigue in horses: review. Turkiye Klinikleri J. Vet. Sci. 6(2):60-66. <http:// dx.doi.org/10.5336/vetsci.2016-51263>

Di Filippo P.A., Gomide L.M.W., Orozco C.A.G., Silva M.A.G., Martins C.B., Lacerda Neto J.C. \& Santana Á.E. 2009. Changes in electrolytes and blood gases in arabian horses during $60 \mathrm{~km}$ endurance race. Ciênc. Anim. Bras. 10(3):840-846. <http://dx.doi.org/10.5216/cab.v10i3.1535>

Draoui N. \& Feron 0. 2011. Lactate shuttles at a glance: from physiologigal paradigms to anti-cancer treatments. Dis. Model Mech. 4(6):727-732. <https://dx.doi.org/101242/dmm.007724><PMid:22065843>

Feher J. 2017. Hypothalamus and pituitary gland, p.870-882. In: Ferrer J. (Ed.), Quantitative Human Physiology: an introdution. 2nd ed. Academic Press, U.S.A.

Gomes C.L.N., Ribeiro Filho R.F., Silva L.P., Aranha R.M.C., Moraes Júnior F.J., Cardoso J.K.M. \& Monteiro L.C. 2019. Physiological and biochaemical parameters of horses in three-barrel training: post-warm-up, post-exercise and post-rest. Arq. Bras. Med. Vet. Zootec. 71(2):631-639. <https://dx.doi. org/10.1590/1678-4162-10270>

Gomes C.L.N.G., Alves A.M., Ribeiro Filho J.D., Moraes Junior F.J., Chaves R.M., Aranha R.M.C., Fucuta R.S. \& Ribeiro B.M. 2020. Exercise training sessioninduced metabolic acidosis in barrel racing horses Acidose metabólica induzida por sessão de treinamento em equinos de tambor. Ciênc. Rural 50(5):e20180887 <http://dx.doi.org/10.1590/0103-8478cr20180887>

Goméz H. \& Mizok B.A. 2017. Hyperlactatemia and lactic acidosis, p.394404. In: Ronco C., Bellomo R., Kellum J.A. \& Ricci Z. (Eds,), Critical Care Nephrology. 3rd ed. Elsevier, Philadelphia.

Gondin M.R., Foz N.S.B., Pereira M.C., Flagliari J.J., Orozco C.A.G., D’Angelis F.H.F., Queiroz-Neto A. \& Ferraz G.C. 2013. Acute Phase responses of different positions of high-goal (elite) polo ponies. J. Equine Vet. Sci. 33(11):956961. <https://dx.doi.org/10.1016/j.jevs.2013.02.005>
Hunka M.M., Souza L.A., Almeida T.H.S., Nery P.C.R., Manso H.E.C.C.C. \& Manso Filho H.C. 2018. Metabolic and physiological changes during and after vaquejada exercise in horses. Med. Vet., Recife, 12(4):254-262.<https:// dx.doi.org/10.26605/medvet-v12n4-2454>

Janicki B., Kochowicz A., Cigan-Szczezielniak D. \& Krumrych W. 2012. Fundamental of exercise physiology in horse. Med. Weter. 68(6):326-327.

Lacerda-Neto J.C., Sampaio R.C.L., Ferraz G.C., Teixeira-Neto A.R., Pereira D.M., Titto E.A.L., Carvalho M.B. \& Queiroz-Neto A. 2003. Effects of intermittent water cooling and electrolyte supplements on serum osmolality and electolytes of horses during low-intensity exercise. Revta Port. Ciênc. Vet. 98(548):189-195.

Linhares J.M., Di Filippo P.A., Bogossian P.M., Guerra R.V.B.A., Bustamante S.R.B., Carvalho C.B. \& Ferreira F.S. 2017. Physical exercise on serum electrolytes and acid base balance in mangalarga marchador horses submitted to cavalcade of 4, 8 and 20km. Ciênc. Rural 47(5):1-6. <https:// dx.doi.org/10.1590/0103-8478cr20160277>

McGowan C.M. \& Hogdson D.R. 2014. Haematology and biochemistry, p.5668. In: Hodgson D.R., McKeever K.H. \& McGowan C.M. (Eds), The Athletic Horse. 2nd ed. Elsevier Saunders, China.

McKeever K.H., Hinchcliff K.W., Reed S.M. \& Robertson J.T. 1993. Role of decreased plasma volume in hematocrit alterations during incremental treadmill exercise in horses. Am. J. Physiol. 265(2 Pt 2):404-408. <https:// dx.doi.org/10.1152/ajpregu.1993.265.2.R404><PMid:8368395>

Monteiro L.C., Ribeiro Filho J.D., Dantas W.M.F., Ribeiro B.M., Silva M.O, Costa C.M., Ermita P.A.N., Silva G.M.M. \& Campos C.H.C. 2018. Effect of ad libitum intake of an electrolyte repository in horses that underwent a polo game. Semina, Ciênc. Agrárias 39(1):187-198. <https://dx.doi.org/10.5433/16790359.2018v39n1p187>

Moreira D.O., Leme F.O.P., Marques M.M., Leão N.F., Viana W.S., Faleiros R.F. \& Alves G.E.S. 2015. Concentrações de proteínas totais, glicose, cálcio, fósforo, lactato, ureia e creatinina em equinos de cavalaria militar antes e após trabalho de patrulhamento urbano. Ciênc. Anim. Bras. 16(1):73-80. <https://dx.doi.org/10.1590/1089-6891v16i115233>

Muriel M.G. 2007. Equilíbrio hidroeletrolítico, p.87-101. In: Boffi F.M. (Ed.), Fisiolgia del Ejercicio en Equinos. Inter-Médica, Buenos Aires.

Padilha F.G.F., Dimache L.A.G., Almeida F.Q. \& Ferreira A.M.R. 2017. Blood biochemical parameters of Brazilian sport horses under training in tropical climate. Revta Bras. Zootec. 46(8):678-682. <https://dx.doi.org/10.1590/ s1806-92902017000800008>

Piccione G., Giannetto C., Costa A., Fazio F. \& Caola G. 2007. Effects of high intensity exercise on serum electrolytes and protein in thoroughbred horses. Magy Allatorvosok Lapja 129(4):208-213.

Prado R.O.F., Morales B.J.E., García M.L., Molina-Ochoa J., Valpuesta S.G., Hernández R.J.A. \& García C.A.C. 2019. Effects of exercise on cations/ anions in blood serum of English Thoroughbred horses. Arq. Bras. Med. Vet. Zootec. 71(3):909-916. <https://dx.doi.org/10.1590/1678-4162-10830>

Rodrigues I.M.S.M.M., Spindola B.F. \& Botteon P.T.L. 2016. Biochemical and oxidative profile of horses used in simulated three-barrel test. Revta Bras. Med. Vet. 38(supl.2):93-100.

Rose R.J., Allen J.R., Hodgson D.R. \& Stewart J.H. 1983. Responses to sumaximal treadmill exercise in the horses: changes in haematology, arterial blood gas and acid base measurements, plasma biochemical values and heart rate. Vet. Rec. 113(26/27):612-618. <PMid:6665971>

Snow D. \& Valberg S. 1994. Muscle anatomy, physiology and adaptations to exercise and training, p.145-179. In: Hodgson D.R. \& Rose R.J. (Eds), The Atletic Horse: principles and practice of equine sports medicine. W.B. Saunders, Philadelphia.

Souza L.A., Hunka M.M., Nery P.C.R., Coelho C.S., Manso H.E.C.C.C. \& Manso Filho H.C. 2018. The effect of repeated barrel racing on blood biomarkers and physiological parameters in Quarter Horses. Comp. Exerc. Physiol. 14(1):47-54. <https://dx.doi.org/10.3920/CEP170019> 
Toribio R. 2008. Essentials of equine renal and urinary tract physiology. Vet. Clin. N. Am., Equine Pract. 23(3):533-561. <https://dx.doi.org/10.1016/j. cveq.2007.09.006><PMid:8061849>

Vermeulen R., Meeûs C., Plancke L., Boshuizen B., Bruijn M. \& Delesalle C. 2017. Effects of training on equine muscle physiology and muscle adaptations in response to different training approaches. Vlaams Diergen. Tijds. 86:224230. <https://dx.doi.org/10.21825/vdt.v86i4.16183>

Vlasakova K., Lane P., Michna L., Muniappa N., Sistare F.D. \& Glaab W.E. 2017. Response of novel skeletal muscle biomarkers in dogs to drug-induced skeletal muscle injury or sustained endurance exercise. Toxicol. Sci. 156(2):422-427. <https://dx.doi.org/10.1093/toxsci/kfw262>

Walker E.J. \& Collins S.A. 2017. The effect of exercise intensity and use of an electrolyte supplement on plasma electrolyte concentrations in the standardbred horse. Can. J. Anim. Sci. 97(4):668-672. <https://dx.doi. org/10.1139/CJAS-2016-0189>
Wallsten H., Olsson K. \& Dahlborn K. 2012. Temperature regulation in horses during exercise and recovery in a cool environment. Acta Vet. Scand. 54(1):42. <https://dx.doi.org/10.1186/1751-0147-54-42><PMid:22805591>

Westerblad H. 2016. Acidosis is not a significant cause of skeletal muscle fatigue. Med. Sci. Sports Exerc. 48(11):2339-2342. <https://dx.doi. org/10.1249/MSS.0000000000001044><PMid:27755383>

Wickler S.J. \& Anderson T.P. 2000. Hematological changes and athletic performance in horses in response to high altitude $(3.800 \mathrm{~m})$. Am. J. Physiol. Regul. Integr. Comp. Physiol. 279(4):R1176-R1181.<https://dx.doi. org/10.1152/ajpregu.2000.279.4.R1176><PMid:11003981>

Zobba R., Ardu M., Niccolini S., Cubeddu F., Dimauro C., Bonelli P., Dedola C., Stefano V, \& Parpaglia M.L.P. 2011. Physical, hematological, and biochemical responsesto acute intense exercise in polo horses. J. Equine Vet. Sci. 31(9):542-548. <https://dx.doi.org/10.1016/j.jevs.2011.03.010> 